\title{
Thermal Classification of Pakistan
}

\author{
Maida Zahid, Ghulam Rasul \\ Research \& Development Division, Pakistan Meteorological Department, Islamabad, Pakistan \\ E-mail: maidazahid.pmd@gmail.com
}

Received June 24, 2011; revised July 29, 2011; accepted August 15, 2011

\begin{abstract}
This research work is designed to carry out the annual and seasonal thermal classification of Pakistan to provide better understanding to all the stake holders like farmers and scientists etc. for obtaining maximum crop yield. The data of Climatic Normal's (1971-2000) has been used to calculate Thornthwaites's Thermal efficiency index for thermal classification of Pakistan. The results of annual thermal classification reveals that Pakistan's northern half experiences Tundra to Microthermal climate type and southern half experiences all types of Mesothermal to Megathermal climate type. Seasonal analysis showed large variations like in winters the whole country ranges from Frost to Microthermal type of climate except the extremely southern parts of the country which have Mild Mesothermal climate. In spring the northern half of the country lies between Tundra to Microthermal climate and southern half from Mesothermal to Megathermal climate. During dry and wet (monsoon) summer season majority of the regions in the country experience Megathermal except Northern areas which show Moderate Mesothermal to Mesothermal climate. The autumn season mostly have Mild Meso- thermal to Tundra climate excluding southern half which showed Moderate Mesothermal to Megathermal climate.
\end{abstract}

Keywords: Evapotranspiration, Thermal Efficiency Index, Tundra and Megathermal

\section{Introduction}

The formulation of climate classification system is very complex. There are different climate classifications developed by various climatologists according to their own criteria. "Climatic classification is merely a method of arranging various climatic parameters either singly or grouped into ranks or sets, so, as both to simplify the mass of data and to identify analogies" [1]. There are many approaches which have been used for climate classifications both for Pakistan and all over world wide. Some of them are the qualitative portrayal of the climate, whereas others are quantitative in nature. These climate classifications are entirely different from each other on the basis of their criteria's. The world climate has been first divided on the basis of solar concentration by Permanide a Greek philosopher. Then the other most well known scientists who did the climate classification are Supan (1896), Koppen (1846-1940), Thornthwaite (1931-1948), Blair (1942), Rodoulf Geiger (1953), Miller (1969) and Griffiths (1978). The former contributors are Kazi (1951), Shamshad (1956) and Nasarullah (1968) who did climate classification of Pakistan [2].
The annual climate indices developed by Koppen [3] are in use world wide, in spite of vast variation among the zones themselves. Koppen classification was temperature based therefore there was some lapse in it. In 1948 Thornthwaite introduce a climate classification on the basis of effective rainfall and Potential Evapotranspiration (PET). This approach was adopted by various regions of the world for classification. The climate of Pakistan has been characterized by adopting Reddy modified Thornthwaite approach using reference crop evapotranspiration (ETo) instead of potential evapotranspiration (PET) [4]. Thornthwaite also developed thermal efficiency index (TEI) for climate classification. The thermal efficiency is a growth index which indicates the thermal periphery and as well as water requirement in different climate types. This approach has also been used by various scientists around the globe [5-11].

The agro climatic classification for Asia and Africa had been done by United Nations Environment Program [12]. Pakistan has arid to semi arid climate with great variability in temperature [13]. Pakistan has been classified into five regions (hot, warm, mild, cool and cold) on the basis of temperature. The southern half experience 
high temperatures and decreases while heading towards northern half of Pakistan. The eastern part of Pakistan receives heavy rainfall in summers due to monsoon while western parts receive heavy rain in winters due to western disturbances. The most suitable area for crop production lies between $33^{\circ} \mathrm{N}$ to $35^{\circ} \mathrm{N}$ due to rain fed conditions. The agricultural production above and below these latitudes is only possible if there is supplementary conditions available for irrigation [13].

\section{Methodology}

The Climatic Normal of 1971-2000 (temperatures, relative humidity, sunshine hours and wind speed data) prepared by Pakistan Meteorological Department (PMD) on monthly basis were used to analyze the thermal classification of Pakistan. The $\mathrm{ET}_{\mathrm{o}}$ calculator has been used to measure Evapotranspiration. $\mathrm{ET}_{\mathrm{o}}$ calculator is software developed by Food and Agriculture Organization (FAO). The main function of this calculator is to calculate evapotranspiration $\left(\mathrm{ET}_{\mathrm{o}}\right)$ according to FAO standards. The $\mathrm{ET}_{\mathrm{o}}$ calculator measures evapotranspiration using meteorological data with the help of FAO Penman-Monteith equation. This method has been selected by FAO as it results in most appropriate value of $\mathrm{ET}_{\mathrm{o}}$ at certain location. The FAO Penmen Montieth method has also been considered best method for Pakistan climate. Evapotranspiration is the combination of two processes commonly known as Evaporation and Transpiration. The loss of water from vegetation both as evaporation from soil and water surface and transpiration from aerial parts of plants. The transpiration mostly takes place through stomata present on the leaves. Both the processes (evaporation and transpiration) occur simultaneously therefore it is very difficult to distinguish between the two processes. It determines the water requirement of crops and as well as potential of agro-climate of a region and suitability of crop varieties, which can possibly be grown profitably with the best economic returns [14]. Annual and Seasonal Thermal Classification of Pakistan has been done by applying Thornthwaite's Thermal Efficiency Index. For seasonal thermal classification five seasons have been considered during the study. These are Winter Season (December-February), Spring (MarchApril), Summer (May-June), Monsoon (July-September) and Autumn (October-November).

Thermal efficiency index is a product of "Temperature” \& calculated "Evapotranspiration”. It is not only a growth index; it gives the idea of growth in terms of the water required for growth (Thornthwaite, 1948). The Thornthwaite climate types according to thermal efficiency index were for large scale area. He defined nine classes out of which Microthermal climate type was divided in two categories i.e. Microthermal $\left(\mathrm{C}_{1}\right.$ and $\left.\mathrm{C}_{2}\right)$ while Mesothermal climate was divided into four climate types like Mesothermal $\left(B_{1}, B_{2}, B_{3}\right.$ and $\left.B_{4}\right)$. These climate types were difficult to understand therefore for simplification and better understanding of these climate types these were redefined in this study. The Thornthwaites's climate types according to thermal efficiency index were downscaled and redefined according to the geography and climate of different regions in Pakistan. For example the Microthermal $\left(\mathrm{C}_{1}\right)$ has been renamed as Mild Microthermal Climate and Microthermal $\left(\mathrm{C}_{2}\right)$ as Microthermal climate. While Mesothermal classes were modified into Mild Mesothermal $\left(\mathrm{B}_{1}\right)$, Moderate Mesothermal $\left(B_{2}\right)$, Strong Mesothermal $\left(B_{3}\right)$ and Mesothermal $\left(\mathrm{B}_{4}\right)$ climate type. Table 1 shows both the original and redefined classes for simplification climate types according to Thornthwaites's Thermal Efficiency Index.

$$
\mathrm{T} \text {-E Index }=\mathrm{T} \text {. ET }
$$

where,

$$
\begin{gathered}
\mathrm{T}=\text { Temperature }\left({ }^{\circ} \mathrm{C}\right) \\
\text { ET }=\text { Evapotranspiration }(\mathrm{cm})
\end{gathered}
$$

Table 1. Thermal climate types based on thornthwaites's thermal efficiency index.

\begin{tabular}{cccc}
\hline TE index & Climate & Type & Redefined types for simplification \\
\hline 14.2 & $\mathrm{E}^{\prime}$ & Frost/Ice & Frost \\
28.5 & $\mathrm{D}^{\prime}$ & Tundra & Tundra \\
42.7 & $\mathrm{C}^{\prime}$ & Microthermal & Mild Microthermal \\
57 & $\mathrm{C}_{2}^{\prime}$ & Microthermal & Microthermal \\
71.2 & $\mathrm{~B}^{\prime}$ & Mesothermal & Mild Mesothermal \\
85.5 & $\mathrm{~B}_{2}{ }^{\prime}$ & Mesothermal & Moderate Mesothermal \\
99.7 & $\mathrm{~B}_{3}{ }^{\prime}$ & Mesothermal & Strongly Mesothermal \\
114 & $\mathrm{~B}_{4}{ }^{\prime}$ & Mesothermal & Mesothermal \\
$>114$ & $\mathrm{~A}^{\prime}$ & Megathermal & Megathermal \\
\hline
\end{tabular}




\section{Results \& Discussion}

\subsection{Annual Thermal Classification}

Pakistan annual average thermal classification lies between Tundra (D) to Megathermal (A) according to Thornthwaites's Thermal Efficiency Index. The extreme northern parts of the country like Gilgit, Skardu and Gupis have Mild Microthermal $\left(\mathrm{C}_{1}\right)$ while Bunji \& Astore areas have Tundra (D) climate. The Microthermal $\left(\mathrm{C}_{2}\right)$ climate type can be observed in northern parts of Khyber Pakhtoonkhwa including Parachinar, Kalat in Balochistan and Azad Kahsmir. The Microthermal climate types are usually observed in humid areas. The Mesothermal climate is divided into four categories by Thornthwaite. The Mesothermal climate is found in sub humid to semi arid environment. The Mild Mesothermal $\left(\mathrm{B}_{1}\right)$ climate is found in Chilas, northwestern areas (Chitral \& Drosh) \& southern parts of Khyber Pakhtoonkhwa and North western parts of Punjab. The distribution of rest of the Mesothermal climate types can be seen in northern and central Punjab, southern Khyber Pakhtoonkhwa and central Balochistan. The Megathermal (A) climate type is usually found in arid areas. The Megathermal (A) climate covers most of the areas of southern Punjab, north eastern and southern parts of Balochistan, entire Sindh including coastal belt. In nutshell, Figure 1 shows that the northern half of the country has Tundra to Microthermal climate types, central and southern half of the country have clear distribution of all kind of Meso- thermal to Megathermal climate types.

\subsection{Seasonal Thermal Classification}

\subsubsection{Winter}

The average temperatures in winter range from $4^{\circ} \mathrm{C}$ to $20^{\circ} \mathrm{C}$. Mercury sometimes falls well below freezing point in Northern parts of the country. Thermal Classification of Pakistan for winter season shows that it starts from climate type Frost (E) and ends at Mild Mesothermal $\left(B_{1}\right)$. The Northern areas including northern half \& extreme western parts of Khyber Pakhtoonkhwa, few areas of Azad Jammu \& Kashmir (Muzaffarabad \& Kotli), Northern Punjab (Murree \& Islamabad) and Balochistan (Zhob, Kalat and Quetta) have frost (E) climate in winters. The Tundra (D) climate covers the entire central Pakistan and extends up to the south western Balochistan. The Sindh province shows variation in climate types from Mild Microthermal $\left(\mathrm{C}_{1}\right)$ to Mild Mesothermal $\left(\mathrm{B}_{1}\right)$. The upper Sindh is Mild Microthermal $\left(\mathrm{C}_{1}\right)$, the central Sindh is Microthermal $\left(\mathrm{C}_{2}\right)$ whereas Lower Sindh have Mild Mesothermal $\left(\mathrm{B}_{1}\right)$ climate due to difference in temperatures. The Balochistan depicts mark distribution in climate types from frost $(\mathrm{E})$ to Mild Mesothermal $\left(\mathrm{B}_{1}\right)$. In Figure 2 the north and south eastern Balochistan show Mild Microthermal $\left(\mathrm{C}_{1}\right)$ climate. The South western and eastern border of Balochistan have Microthermal $\left(C_{2}\right)$ climate whereas the coastal areas at the southern tip of Balochistan shows Mild Mesothermal ( $\left.\mathrm{B}_{1}\right)$ climate.

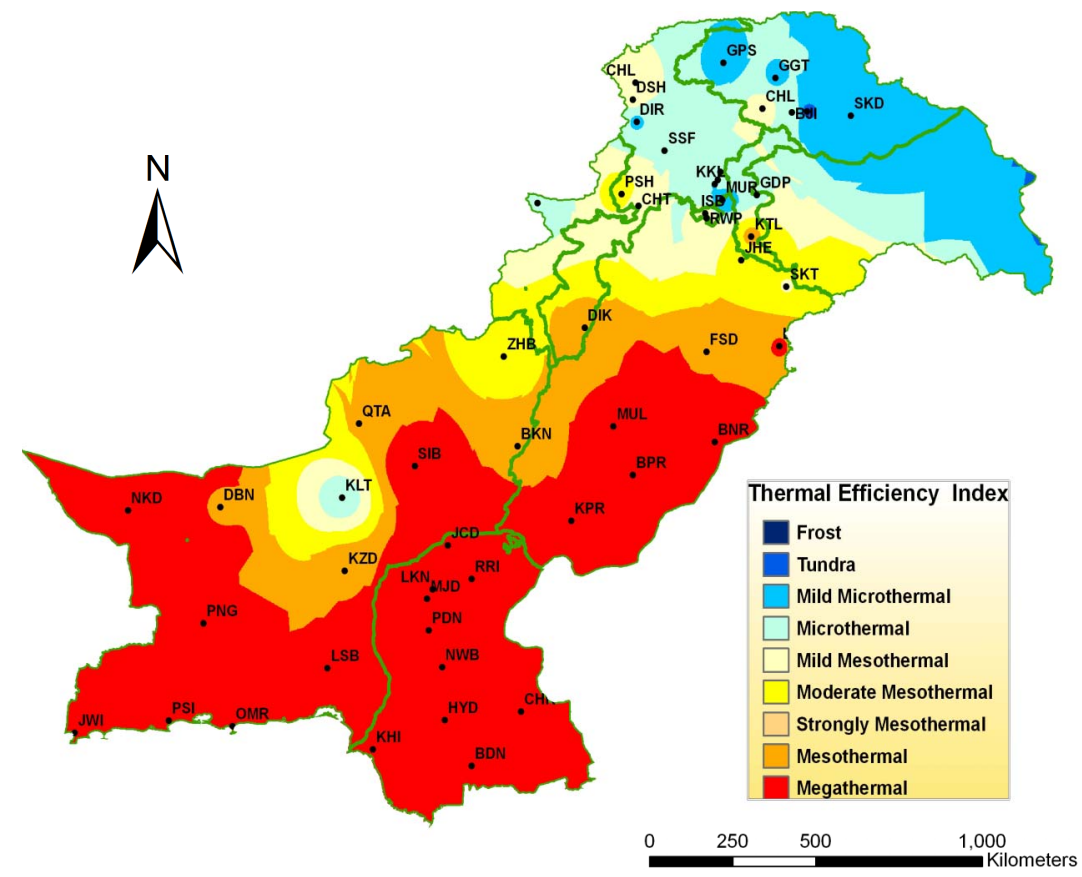

Figure 1. The annual average thermal classification of Pakistan shows Tundra to Megathermal climate. 


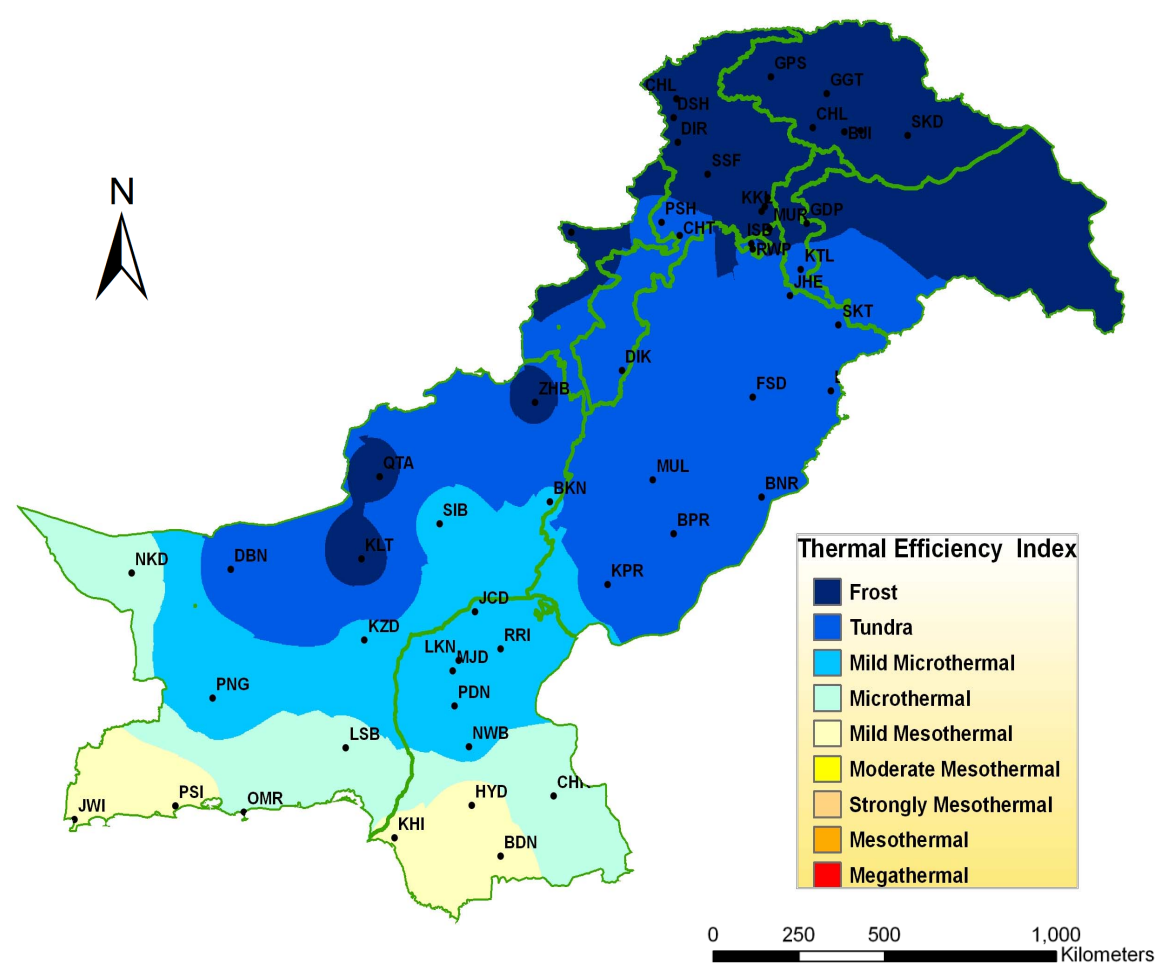

Figure 2. Thermal classification of winter (December-February) in Pakistan shows Frost to Mild Mesothermal climate.

\subsubsection{Spring}

In spring season (March and April) the Northern parts of Pakistan show variety of climate types from Tundra (D) to Microthermal $\left(\mathrm{C}_{2}\right)$ climate. The majority of Northern areas clearly depict the Mild Microthermal climate $\left(\mathrm{C}_{1}\right)$ except Bunji which show Tundra (D) climate type and Chilas have Microthermal $\left(\mathrm{C}_{2}\right)$ climate type as shown in Figure 3. The few stations of north western, south western Khyber Pakhtoonkhwa and an isolated cell in central Balochistan also show Mild Microthermal climate $\left(\mathrm{C}_{1}\right)$. Whereas the north eastern parts of Khyber Pakhtoonkhwa along with adjoining areas of upper Punjab and Azad Kashmir show Microthermal $\left(\mathrm{C}_{2}\right)$ climate during spring season. The central Pakistan covers from Mild Mesothermal $\left(B_{1}\right)$ to Mesothermal $\left(B_{4}\right)$ climate type. An isolated Megathermal (A) climate within Mesothermal $\left(\mathrm{B}_{4}\right)$ climate type can be observed at the border of south eastern Punjab. The Balochistan covers almost all climates from Mild Microthermal ( $\left.B_{1}\right)$ to Megathermal (A) conditions. The entire Sindh, south eastern and extreme southern areas of Balochistan extending from Nokundi to Lasbella lie in Megathermal (A) climate type. The reason can be that temperature start increasing in spring in southern half of the country. The increase in temperature will increase Evapotranspiration and ultimately thermal efficiency index of the area. The water requirement of flora starts increasing towards the southern half of the country during spring.

\subsubsection{Dry Summer}

Summer season from May to June is extremely hot and dry with relative humidity ranges from $25 \%$ to $50 \%$. The day-time temperature in this season remains $40^{\circ} \mathrm{C}$ and beyond in plain areas. In summers the day length and temperature values show high degree of uniformity. Figure 4 illustrates the thermal classification for summers lies between Moderate Mesothermal $\left(B_{2}\right)$ to Megathermal (A) climate. The Moderate Mesothermal $\left(\mathrm{B}_{2}\right)$ climate is found in Astore and along North Eastern border while strongly Mesothermal $\left(\mathrm{B}_{3}\right)$ climate type is found in Skardu and Gupis. The areas like Gilgit, Dir, Parachinar, Murree and Kalat lie in Mesothermal $\left(\mathrm{B}_{4}\right)$ climate. The rest of the entire regions show Megathermal (A) conditions. Therefore the vegetation in the regions of Megathermal climate remains under stress during dry summer period.

\subsubsection{Wet Summer (Monsoon)}

In Monsoon (JAS) Pakistan thermal classification is found between Moderate Mesothermal $\left(\mathrm{B}_{2}\right)$ to Megathermal (A) climate. The Hilly areas like Gilgit, Gupis, Astore, Parachinar, Dir and Kalat show Mesothermal $\left(\mathrm{B}_{4}\right)$ climate while an isolated cell of strongly Mesothermal $\left(\mathrm{B}_{3}\right)$ climate around Skardu can be seen. The Chilas and Bunji 


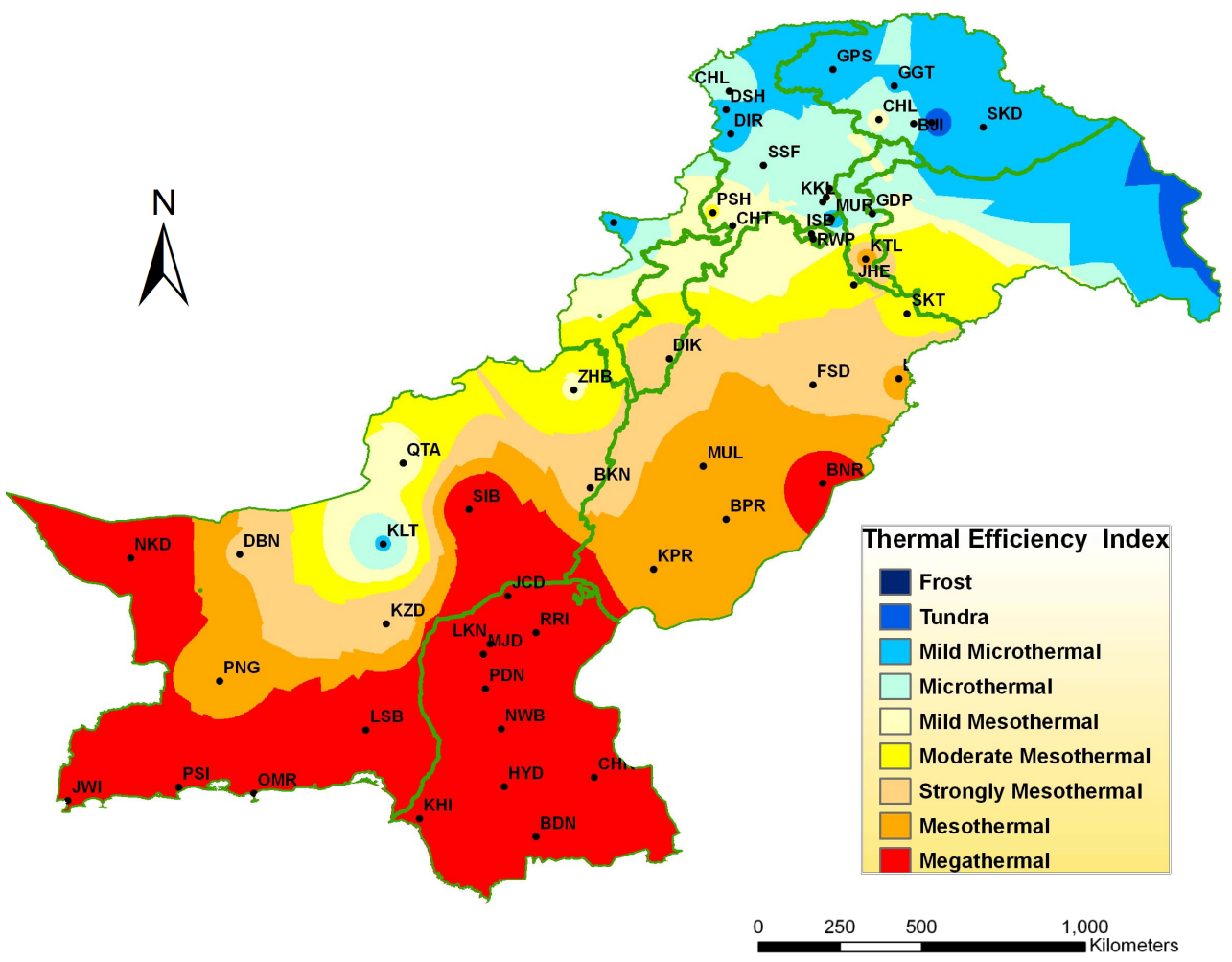

Figure 3. Thermal classification of spring (March-April) in Pakistan shows Tundra to Megathermal climate.

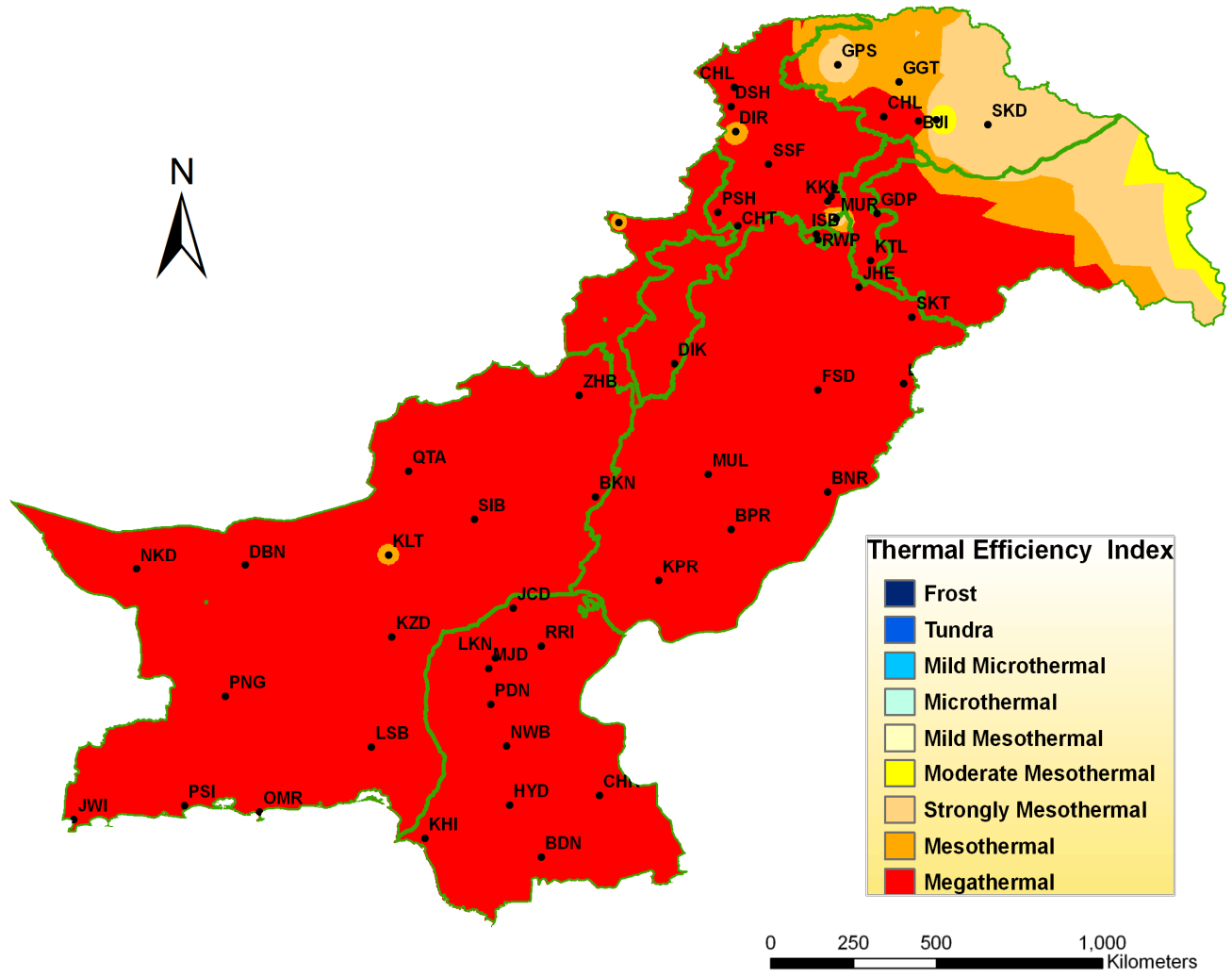

Figure 4. Thermal classification of summer (May-June) in Pakistan shows Moderate Mesothermal to Megathermal climate. 
both are having desert like climate so their aridity and increase in thermal efficiency force them to fall in Megathermal (A) climate type as shown in Figure 5. The areas which are under the affect of monsoon rainfall belt show mark variation in climate type from Moderate Mesothermal $\left(B_{2}\right)$ to Mesothermal $\left(B_{4}\right)$ climate. This variation is because of low temperatures due to more rainfall. Secondly these areas are of Humid to Sub humid climate therefore reduce the rate of Evapotranspiration and hence the thermal efficiency index. The rest of the country lies in Megathermal (A) climate zone. Although during monsoon Pakistan receive a lot of rainfall but still temperatures remain high in almost all over the country affecting plants growth and health.

\subsubsection{Autumn}

The autumn season (October to November) thermal classification lies from Megathermal (A) to Tundra (D) climate. Tundra climate (D) covers almost all the Northern areas and an isolated cell around Dir of Khyber Pakhtoonkhwa. The majority of the stations of Khyber Pakhtoonkhwa and adjoining areas of upper Punjab and Kalat in Balochistan have Mild Microthermal $\left(\mathrm{C}_{1}\right)$ climate. The few stations of southern Khyber Pakhtoonkhwa, northern Punjab, north western Balochistan includ- ing Dalbandin have Microthermal $\left(\mathrm{C}_{2}\right)$ climate during autumn. Southern Punjab, D.I Khan of Khyber Pakhtoonkhwa and Khuzdar of Balochistan show Mild Mesothermal $\left(B_{1}\right)$ climate. An isolation around Bahawalnagar area, Eastern Balochistan, including Panjgur and Lasbella and northern Sindh lie in Moderate Mesothermal $\left(\mathrm{B}_{2}\right)$ climate. The southern Sindh and Balochistan fall between strongly Mesothermal $\left(B_{3}\right)$ to Megathermal (A) climate. The Megathermal (A) area can be seen within Mesothermal $\left(\mathrm{B}_{4}\right)$ climate in western Balochistan and southern Sindh in Figure 6.

\section{Conclusions}

Pakistan experiences variety of thermal zones from Frost (very cold/ice) to Megathermal (very hot/arid) climate type. The annual thermal classification ranges from Mild Microthermal $\left(\mathrm{C}_{1}\right)$ to Megathermal (A) climate. It is concluded on the basis of annual thermal classification that Pakistan's northern half experience Tundra (D) to Microthermal $\left(C_{2}\right)$ climate type and southern half has all types of Mesothermal ( $\left.B_{1}, B_{2}, B_{3}, B_{4}\right)$ to Megathermal (A) climate type. Seasonal analysis shows a lot of deviation in thermal zones throughout the country. In winters, almost the whole country experiences from Microthermal

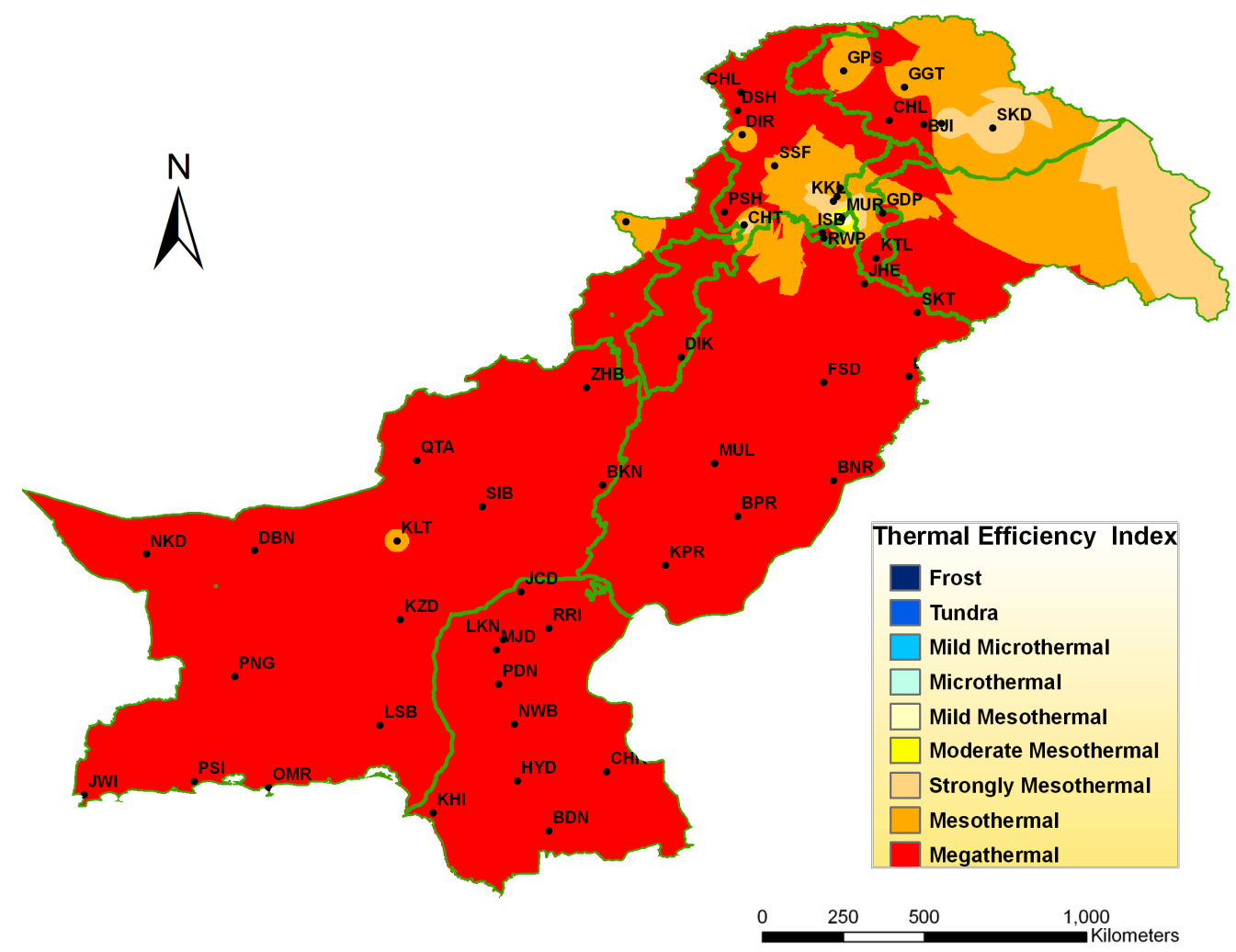

Figure 5. Thermal classification of monsoon (July-September) in Pakistan shows Moderate Mesothermal to Megathermal climate. 


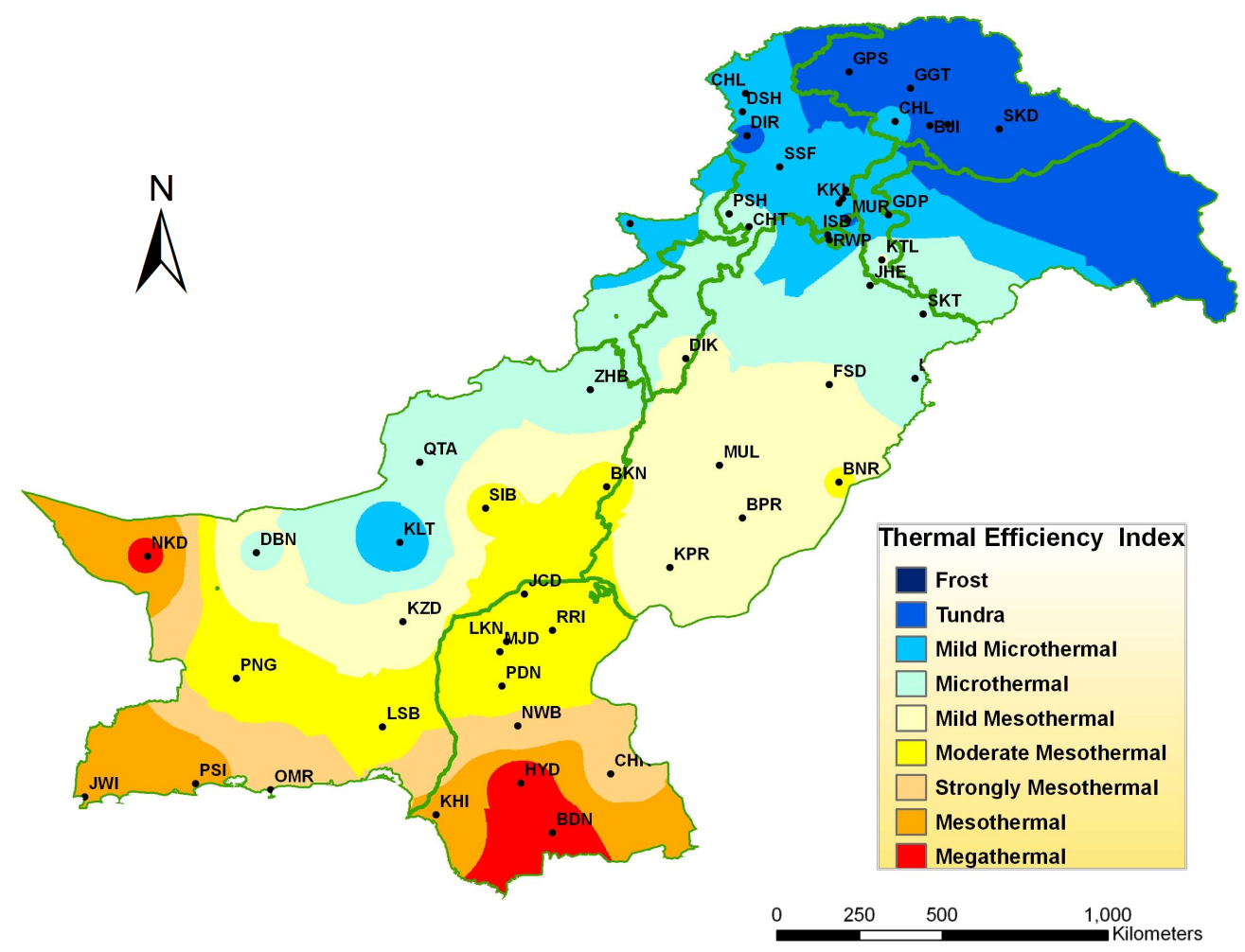

Figure 6. Thermal classification of autumn (October-November) in Pakistan shows Megathermal to Tundra climate.

$\left(\mathrm{C}_{2}\right)$ to Frost (E) Type of climate except the extreme southern parts of the country which has Mild Mesothermal $\left(B_{1}\right)$ climate. During spring season the northern half of the country lies between Tundra (D) to Microthermal $\left(\mathrm{C}_{2}\right)$ climate. The central parts show Mild Mesothermal $\left(B_{1}\right)$ to Mesothermal $\left(B_{4}\right)$ climate types while Southern half of Pakistan show Mesothermal $\left(\mathrm{B}_{4}\right)$ to Megathermal (A) climate. In summer, almost the majority of the regions of Pakistan fall in Megathermal (A) climate type excluding Northern areas which show Moderate Mesothermal $\left(\mathrm{B}_{2}\right)$ to Mesothermal $\left(\mathrm{B}_{4}\right)$ climates. During monsoon, again most of the country show Megathermal (A) climate. Northern areas including some parts of northern half of Pakistan which are under the influence of monsoon rain show demarcation from Moderate Mesothermal $\left(\mathrm{B}_{2}\right)$ to Mesothermal $\left(\mathrm{B}_{4}\right)$ climate. In autumn, the entire country experience Mild Mesothermal $\left(B_{1}\right)$ to Tundra $(D)$ climate with the exception of southern half which has Moderate Mesothermal $\left(B_{2}\right)$ to Megathermal (A) climate.

\section{References}

[1] J. F. Griffiths, “Applied Climatology,” 2nd Edition, Oxford University Press, London, 1978, p. 136.

[2] S. U. Khan, M. Hassan, F. K. Khan and A. Bari, “Climate
Classification of Pakistan,” BALWOIS, Ohrid, 2010, pp. 1-47.

[3] W. Koppen, “Das Geographisca System der Klimate,” In: W. Koppen and G. C. Geiger, Eds., Handbuch der Klimatologie, Gebr, Borntraeger, 1936, pp. 1-44.

[4] S. J. Reddy and R. S. Reddy, "A New Method of Estimation of Water Balance," International Symposium on Tropical Meteorology Meeting American Meteorological Society, Nairobi, 1973, pp. 277-280.

[5] B. J. Garnier, “Thornthwaite's New System of Climatic Classification in Its Application to New Zealand,” Transaction of the Royal Society of New Zealand, Vol. 79, 1951, pp. 87-103.

[6] C. W. Thornthwaite, “An Approach towards a Rational Climate Classification,” Geographical Review, Vol. 38, No. 1, 1948, pp. 55-94. doi:10.2307/210739

[7] M. Sanderson, "The Climates of Canada according to the New Thornthwaite Classification," Scientific American, Vol. 28, 1948, pp. 501-517.

[8] S. Erinc, "Climatic Types and the Variation of Moisture Regions in Turkey,” Geographical Review, Vol. 40, No. 2, 1950, pp. 224-235. doi:10.2307/211281

[9] G. Howe, "Climates of the Rhodesias and Nyasaland according to the Thornthwaite Classification," Geographical Review, Vol. 43, No. 4, 1953, pp. 525-539. doi:10.2307/212037

[10] J. Chang, "The Climate of China according to the New 
Thornthwaite Classification," Annals of the Association of American Geographers, Vol. 45, No. 4, 1955, pp. 393-403. doi:j.1467-8306.1955.tb01494.x

[11] J. R. Villmow, "Regional Pattern of Climates in Europe according to the Thornthwaite Classification," The Ohio Journal of Science, Vol. 62, No. 1, 1962, pp. 39-53.

[12] D. H. White, "A Global Analysis of the Distribution and Production of the Livestock Communities,” Report No 30 UNEP, ASIT Consulting, Hawker, 1998, pp. 3-17.
[13] Q. Z. Chaudhary and G. Rasul, “Agro-Climatic Classification of Pakistan,” Science Vision, Vol. 9, No. 1-4, 2004, pp. 59-66.

[14] Climatical Normal (1971-2000) of Pakistan, Pakistan Meteorological Department, Karachi, 2005.

[15] G. Rasul and A. Mahmood, "Performance Evaluation of Different Methods for Estimation of Evapotranspiration in Pakistan's Climate," Pakistan Journal of Meteorology, Vol. 5, No. 10, 2009, pp. 25-36. 